Haptic Modernism 
For Randall Stevenson, who made a modernist of me. 


\section{Haptic Modernism}

Touch and the Tactile in Modernist Writing

Abbie Garrington 
(C) Abbie Garrington, 2013

Edinburgh University Press Ltd

22 George Square, Edinburgh EH8 9LF

www.euppublishing.com

Typeset in 10.5/13 pt Sabon

by Servis Filmsetting Ltd, Stockport, Cheshire, and

printed and bound in Great Britain by

CPI Group (UK) Ltd, Croydon CR0 4YY

A CIP record for this book is available from the British Library

ISBN 9780748641741 (hardback)

ISBN 9780748682539 (webready PDF)

ISBN 9780748682546 (epub)

The right of Abbie Garrington

to be identified as author of this work

has been asserted in accordance with

the Copyright, Designs and Patents Act 1988. 